 \\ S ENGINEERING CHANGE NOTICE
}

\begin{tabular}{|c|c|c|c|c|}
\hline \multicolumn{2}{|l|}{$\begin{array}{l}\text { 2. ECN Category } \\
\text { (mark one) }\end{array}$} & $\begin{array}{l}\text { 3. Originator's Name, Organization, MSIN, and } \\
\text { Telephone No. } \\
\text { HF Shumake Jr. 08E00 } \quad \text { S7-12 } \quad 6-3404\end{array}$ & $\begin{array}{l}\text { 4. USQ Required? } \\
\text { [l] Yes }[X] \text { No }\end{array}$ & $\begin{array}{l}\text { 5. Date } \\
\qquad 11 / 29 / 99\end{array}$ \\
\hline $\begin{array}{l}\text { Direct Revision } \\
\text { Change ECN }\end{array}$ & {$[\mathrm{X}]$} & $\begin{array}{l}\text { 6. Project Title/No./Work Order No. } \\
\text { Characterization Project / CACN } 102250\end{array}$ & $\begin{array}{c}\text { 7. Bldg./Sys.Fac. No. } \\
200 \mathrm{G}\end{array}$ & $\begin{array}{l}\text { 8. Approval Designator } \\
\text { ESQ }\end{array}$ \\
\hline $\begin{array}{l}\text { Standby } \\
\text { Supersedure } \\
\text { Cancel/Void }\end{array}$ & $\begin{array}{l}{[} \\
{[]} \\
{[]}\end{array}$ & $\begin{array}{l}\text { 9. Document Numbers Changed by this } \mathrm{ECN} \\
\text { (includes sheet no. and rev.) } \\
\text { HNF-4740. Rev. } 0\end{array}$ & 10. Related ECN No(s). & 11. Related PO No. \\
\hline
\end{tabular}

\begin{tabular}{|c|c|c|c|}
\hline 12a. Modification Work & $\begin{array}{l}\text { 12b. Work Package } \\
\text { No. }\end{array}$ & 12c. Modification Work Complete & $\begin{array}{l}\text { 12d. Restored to Original Condition (Temp. } \\
\text { or Standby ECN only) }\end{array}$ \\
\hline $\begin{array}{l}\text { [] Yes (fill out Blk. 12b) } \\
{[\mathrm{x}] \text { No (NA Blks. 12b, }} \\
\text { 12c, 12d) }\end{array}$ & N/A & $\frac{\mathrm{N} / \mathrm{A}}{\mathrm{c} \begin{array}{c}\text { Design Authority/Cog. Engineer } \\
\text { Signature \& Date }\end{array}}$ & $\begin{array}{c}\underline{\mathrm{N} / \mathrm{A}} \\
\begin{array}{c}\text { Design } \\
\text { Authority/Cog. Engineer } \\
\text { Signature \& Date }\end{array}\end{array}$ \\
\hline
\end{tabular}

The scope of testing on the Grapple Hoist Assembly was increased. This ECN will incorporate testing of the leveler plate design as well as a release and repeatability test and testing with a fixative agent applied.

The changes being made are of an administrative nature and therefore do not require a NEPA screen.

$\begin{array}{llllllll}\text { 14a. Justification (mark one) } & & & & \\ \text { Criteria Change } & {[\mathrm{X}]} & \text { Design Improvement } & \text { [] } & \text { Environmental } & {[]} & \text { Facility Deactivation } \\ \text { As-Found } & {[]} & \text { Facilitate Const } & {[]} & \text { Const. Error/Omission } & {[]} & \text { Design Error/Omission [] }\end{array}$

14b. Justification Details

- Additional testing has been requested to ensure that the Grapple Hoist components will function under conditions similar to those encountered in the actual fielded environment. This testing is intended to demonstrate that the new leveler plate design prevents a slack cable condition on the drum which contributes to the "bird-nesting" problems encountered during field use.

15. Distribution (include name, MSIN, and no. of copies)

$\begin{array}{llllll}\text { R. N. Dale } & \text { S7-12 } & \text { 1 COPY } & \text { E. E. Salinas } & \text { S7-12 } & 1 \text { COPY } \\ \text { G. P. Janicek } & \text { S7-12 } & \text { 1 COPY } & \text { G. W. Wilson } & \text { S7-12 } & 1 \text { COPY } \\ \text { H.F. Shumake Jr. } & \text { S7-12 } & \text { 1 COPY } & & & \end{array}$

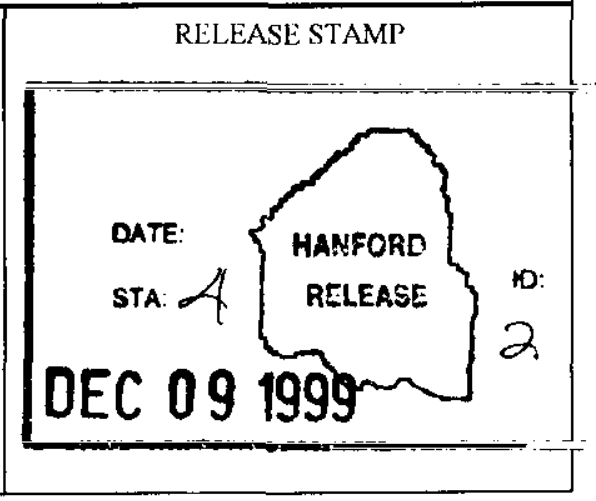




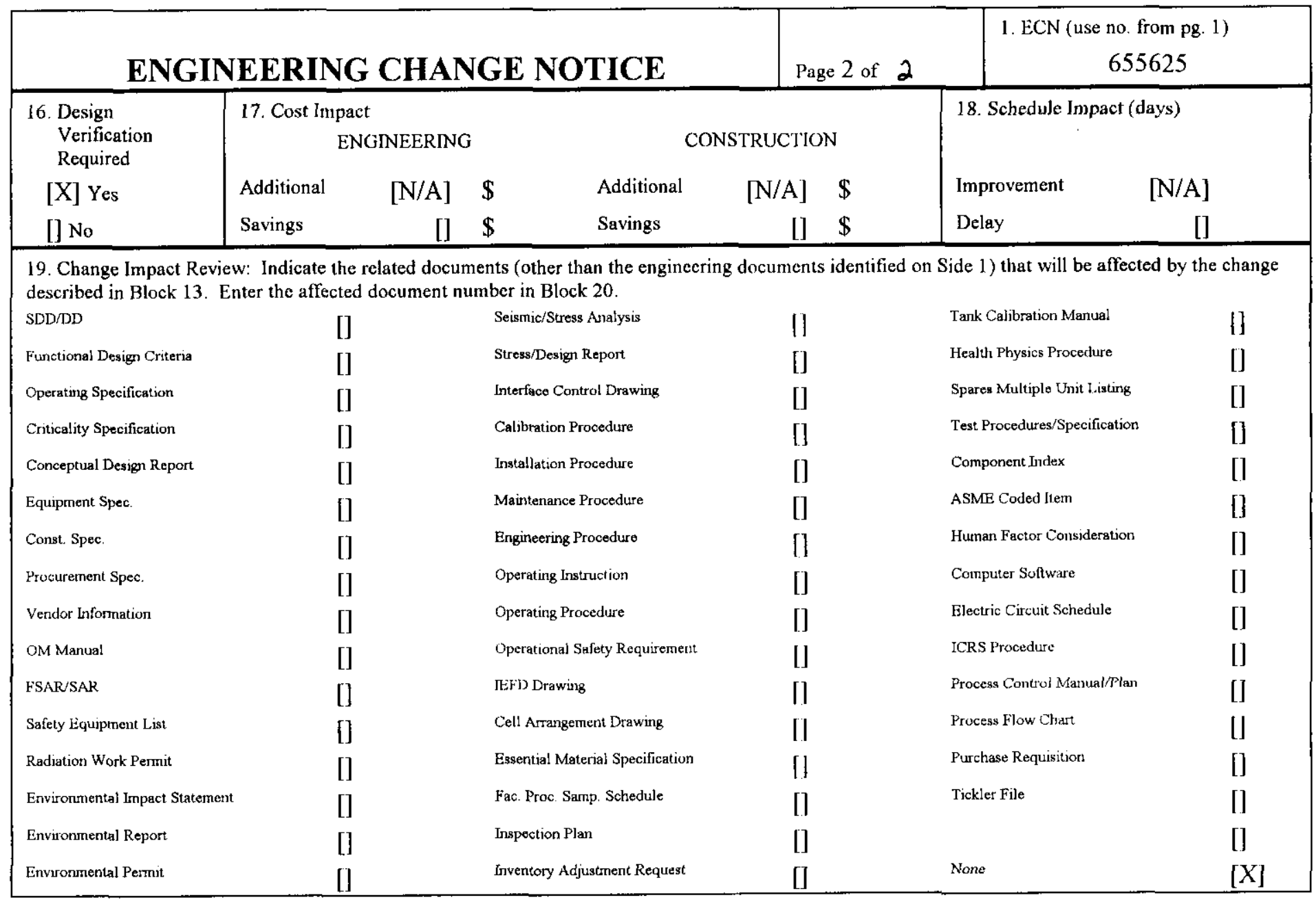

20. Other Affected Documents: (NOTE: Documents listed below will not be revised by this ECN.) Signatures below indicate that the signing organization has been notified of other affected documents listed below.
Document Number/Revision
Document Number/Revision
Document Number Revision
N/A
N/A
N/A

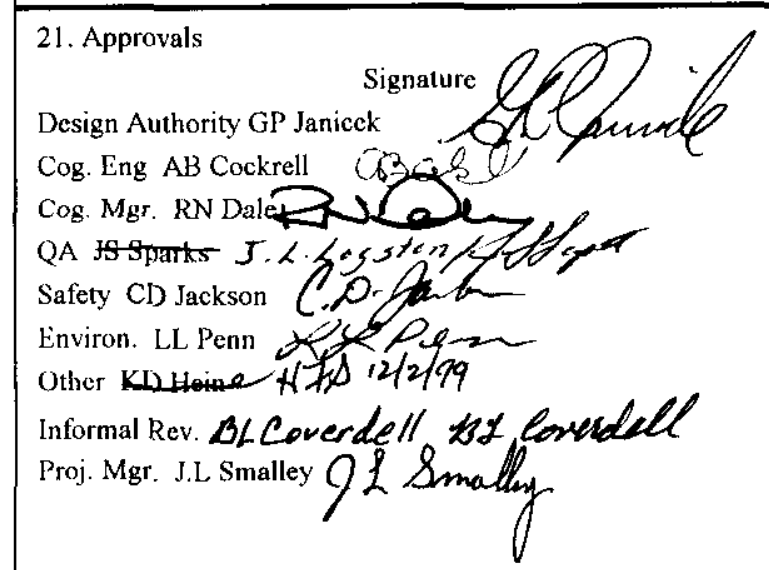

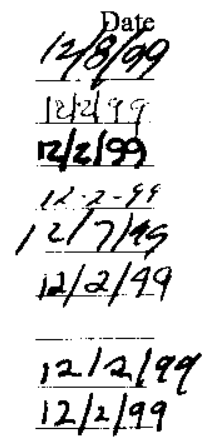

$12 / 2 / 99$
Signature

Date

Design $\Lambda g e n t$

PE

QA

Safety

Design

Environ.

Other

DFPARTMENT OF ENERGY

Signature or a Control Number that tracks the Approval Signature 


\section{Test Plan for Rotary Mode Core Sample Truck Grapple Hoist Level Wind System}

\section{RM Boger}

Prepared by Lockheed Martin Hanford, Inc.

Richland, WA 99352

U.S. Department of Energy Contract DE-AC06-96RL13200

ECN: 655625

Org Code: 74900

B\&R Code: EW3120074
UC: 2070

Charge Code: $102250 /$ B000

Total Pages: 26

Key Words: Waste Sampling, RMCS, RMCST, Grapple Hoist, Level Wind

Abstract: This test plan describes the acceptance criteria, test parameters, test apparatus, test procedures, and testing personnel for the qualification testing of the Grapple Hoist Level Wind System.

TRADEMARK DISCL.AIMER. Reference herein to any specific commercial product, process, or service by trade name, trademark, manufacturer, or otherwise, does not necessarily constitute or imply its endorsement, recommendation, or favoring by the United States Government or any agency thereof or its contractors or subcontractors.

Printed in the United States of America. To obtain copies of this document, contact: Document Control Services, P.O. Box 950, Mailstop H6-08, Richland WA 99352, Phone (509) 372-2420; Fax (509) 376-4989.

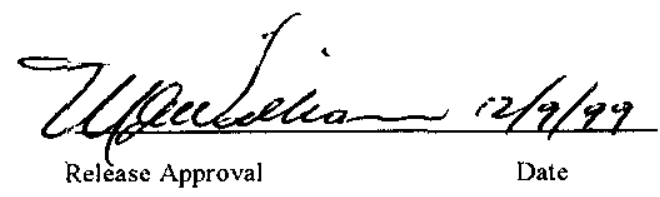

Approved for Public Release

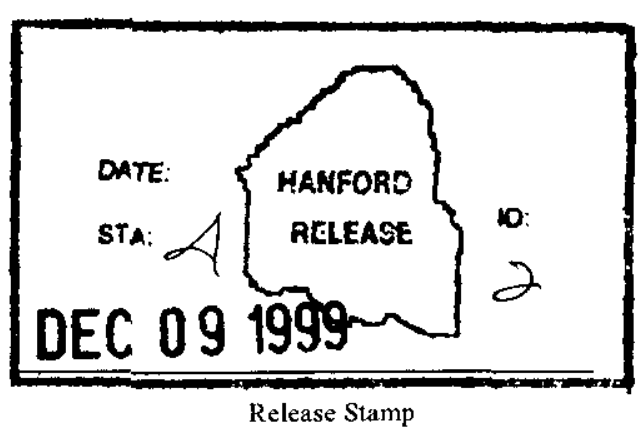

Release Stamp 
RECORD OF REVISION

(1) Document Number
HNF-4740, Rev. 0

Page

(2) Title

Test Plan for Rotary Mode Core Sample Truck Grapple Hoist Level Wind system

Change Control Record

(3) Revision

1 RS
(7)

(4) Description of Change - Replace, Add, and Delete Pages

neche

design as well as a release and repeatability

test and testing with a fixative agent applied.

Entire document revised.

ECN -655625
Authorized for Release

\begin{tabular}{l|ll} 
(5) Cog. Engr. & (6) Cog. Mgr. Date
\end{tabular}

ABcoussell :260199

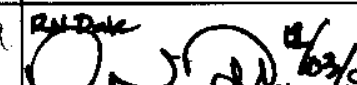

ige 
HNF-4740, Rev. 1

\title{
TEST PLAN FOR ROTARY MODE CORE SAMPLE TRUCK GRAPPLE HOIST LEVEL WIND SYSTEM
}

\author{
Prepared for \\ River Protection Project \\ Characterization Engineering \\ Lockheed Martin Hanford Corporation \\ Richland, Washington \\ Prepared by \\ H. F. Shumake Jr. \\ COGEMA Engineering Corporation
}

December 1999 


\section{TABLE OF CONTENTS}

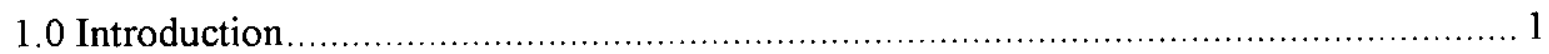

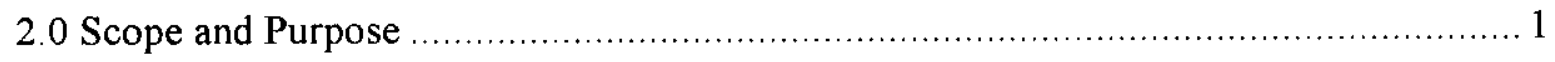

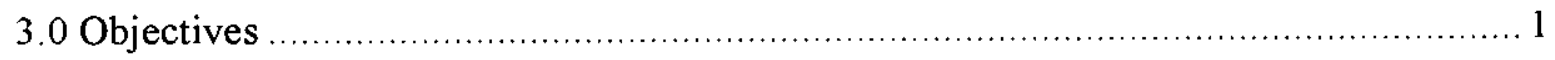

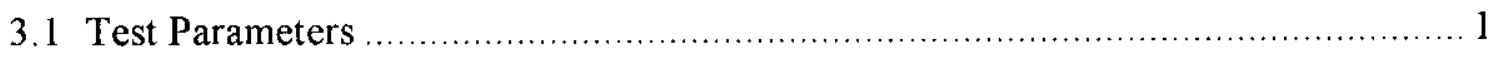

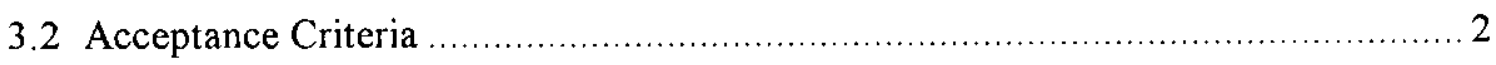

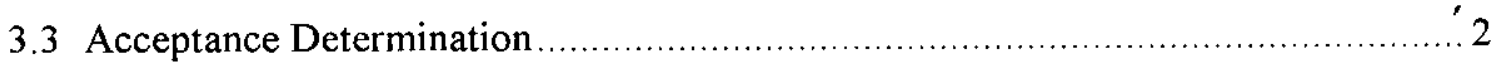

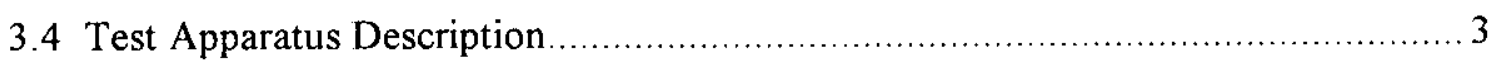

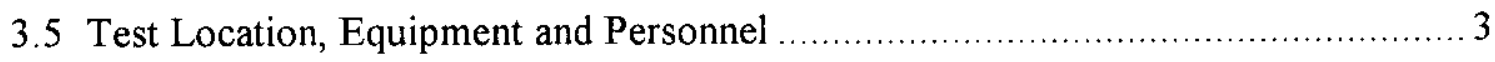

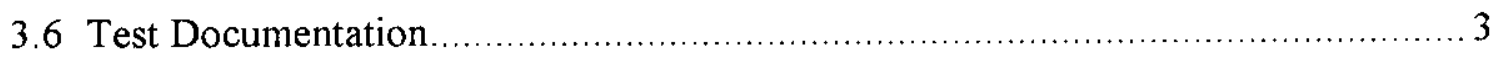

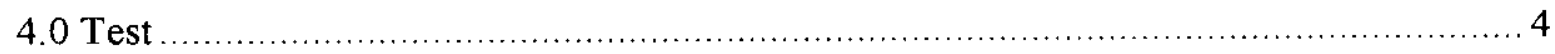

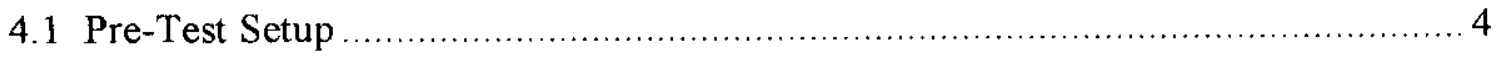

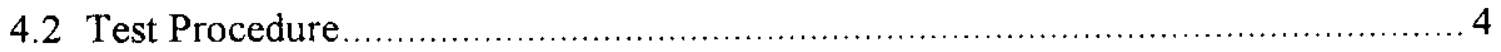

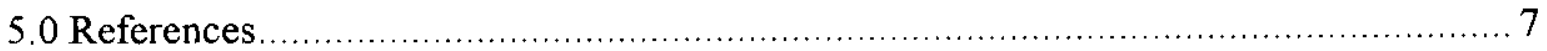




\subsection{INTRODUCTION}

A Grapple Hoist Assembly is currently used on the Rotary Mode Core Sampling Trucks (RMCSTs) to actuate the sampler and retrieve the pintle rod during sampling operations. The hoist assembly includes a driven drum approximately two inches wide and six inches in diameter that rotates to pay out or reel in the 5/32-in. cable. The current Grapple Hoist Assembly, detailed on drawing H-2-690057, is prone to "bird nesting" the cable on the drum. "Bird nesting" is a condition in which the cable does not wind onto the drum in a uniformly layered manner, but winds in a random fashion where the cable essentially "piles up" inappropriately on the drum and, on some occasions, winds on the drum drive shaft. A system to help control this "bird nesting" problem has been designed as an addition to the existing components of the Grapple Hoist Assembly. The new design consists of a mechanism that is timed with, and driven by, the shaft that drives the drum. This mechanism traverses back and forth across the width of the drum to lay the cable on the drum in a uniformly layered manner.

This test plan will be approved, released, revised, and accounted for according to the provisions of Supporting Document Requirements (LMHC 1999a).

\subsection{SCOPE AND PURPOSE}

This test plan establishes the acceptance criteria, test procedure and test conditions. It also describes the test apparatus necessary to verify the adequacy of the level wind system design. The test is defined as qualification testing (LMHC 1999b) and as such will be performed at conditions beyond the parameters that the Grapple Hoist Assembly is allowed to operate by the Safety Equipment List (SEL)(LMHC 1998).

\subsection{OBJECTIVES}

The objectives of this test are to establish whether the Grapple Hoist Level Wind Assembly will eliminate the likelihood of "bird nesting" to an acceptable level under a variety of loading conditions, and to determine if the components are capable of carrying the required loads. An additional test will be performed to determine the adequacy of a newly designed leveler plate which also aids in preventing a "bird nesting" condition. A "fixative" test will be performed to ensure that the product used as a fixative in the process of decontamination does not cause a problem with the operation of the Grapple Hoist components. A release and repeatability test will be performed to verify that the "shock load" encountered when the pintle rod is removed from a sampler does not affect the performance of the level wind components or the leveler plate; it will also be used to ensure that the load cell readings are repeatable.

\subsection{TEST PARAMETERS}

The operating parameters of the Grapple Hoist Level Wind Assembly are limited by the SEL (LMHC 1998). Specifically the shaft connected to the cable drum shall not rotate at a rate greater than 27 revolutions/minute. A rate of $27 \mathrm{rev} / \mathrm{min}$ will prevent the drum, shaft and roll pins, inside the grapple hoist box, from attaining a relative motion greater 
than $30 \mathrm{~cm} / \mathrm{sec}$. In addition, the maximum allowable operating load of the Grapple Hoist Assembly is $1112 \mathrm{~N}$ ( $250 \mathrm{lbf}$ ). The cable is $24.38 \mathrm{~m}$ ( $80 \mathrm{ft}$.) long, a minimum of 3 wraps of the cable on the drum will yield a testable length of approximately $22 \mathrm{~m} \mathrm{(72ft.).} \mathrm{The}$ test(s) shall be performed using the maximum useful/testable length of cable.

\subsection{ACCEPTANCE CRITERIA}

The loads used for testing, as well as the load approximation/description, are shown in Table 1. Each of the loads shall be repeated 25 times for the effective cable length of approximately $22 \mathrm{~m}(72 \mathrm{ft}$.).

3.2.1 The Grapple Hoist Level Wind Assembly shall prevent the condition of "bird nesting" under the loads shown in Table 1.

NOTE: Cable alone test is for information only-this load condition is not to be used for acceptance/rejection.

3.2.2 The Grapple Hoist Level Wind Assembly shall not show damage or excessive wear of its parts nor any signs that the components have malfunctioned.

3.2.3 The "fixative" shall not cause the Grapple Hoist Level Wind assembly to malfunction, accelerate wear, or cause repeatability problems.

\begin{tabular}{|c|c|}
\hline \multicolumn{2}{|c|}{ Table 1-Load Conditions } \\
\hline $\begin{array}{c}\text { Intended } \\
\text { Load } \\
(\mathrm{N} /(\mathrm{lbf}))\end{array}$ & Condition/Load approximation/Description \\
\hline Cable Alone & Self-explanatory-this load condition being tested for information only. \\
\hline $111 /(25)^{*}$ & Approximate weight of the grapple \\
\hline $445 /(100)^{*}$ & Approximate weight of the grapple + approximate release force of pintle rod \\
\hline $890 /(200)^{*}$ & 2 X (approximated grapple weight + release force) \\
\hline $1112 /(250)^{*}$ & Slightly greater than the maximum force allowed by the SEL. \\
\hline The actual loads suspended are to be $+/-5 \%$ of the intended loads. \\
\hline * The weight of the cable is additive to these loads. \\
\hline
\end{tabular}

\subsection{ACCEPTANCE DETERMINATION}

The acceptance criteria that are noted in section 3.2 require further definition to prevent the qualitative nature of this test from potential corruption due to potential differing interpretation of the criteria. The following definitions apply, respectively, to the acceptance criteria in section 3.2. The following definitions apply in the context of this document and the test report that will be released after this test has been performed.

3.3.1 "Bird Nesting"-will have occurred when the cable piles up on the drum three layers higher than the lowest uncovered wrap of cable on the drum. 
3.3.2 The judgement of the engineer, as well as that of the Characterization Project Operations (CPO) assigned Quality Assurance (QA) personnel, will be used to determine if excessive wear, damage, or component failure has occurred after the series of loads have been applied. If desired, the cognizant engineer and design authority can inspect the components for excessive wear, damage, and component failure.

\subsection{TEST APPARATUS DESCRIPTION}

The test apparatus will consist of a mock-up grapple hoist box, an electric motor, gear reduction unit, brake, load cell and display and peripherals necessary for operation. The mock-up will be functionally equivalent to the setup detailed on the unreleased Grapple Hoist Assembly (Development Control) drawing and the Grapple Hoist Installation drawing. The majority of the electrical drive components used in the test will be retrieved from spares located in building $2101 \mathrm{HV} / 200 \mathrm{E}$ (warehouse). The electrical details can be found on the Electrical Connection Diagrams drawing. The rotational rate of the drum will be approximately $27 \mathrm{rpm}$. The motor will actuate the drum and timed level wind assembly. The loat cell will be replaced by a fastener that will maintain a similar position in the "teeter-totter" assembly. The load will be applied to the cable by hanging a prescribed amount of weight from the cable body via a tool that will be repositioned along its length without causing cable damage. A "suspension tool" is necessary to grip the body of the cable because the $22 \mathrm{~m}$ ( $72 \mathrm{ft}$.) length of cable can't be tested without being repositioned due to the height of available test facilities. Sketches of the test apparatus are contained in Appendix A.

\subsection{TEST LOCATION, EQUIPMENT AND PERSONNEL}

The test of the Grapple Hoist Level Wind Assembly is to be performed onsite, most likely, at the Engineering Testing Laboratory (ETL). The auxiliary test equipment necessary to perform the test will be supplied by the ETL. The auxiliary equipment/facilities that are needed for the test are a suitable area to mount and operate the hoist, to include safety railing, with a minimum height from the bottom of the hoist to the "floor" of $3.88 \mathrm{~m}$ (12 ft.); 110 VAC grounded power and extension cords, if required; calibrated, or verifiable, scale (minimum range of 0 to $1556 \mathrm{~N}(0$ to $350 \mathrm{lbf})$ ) to determine the actual suspended weight; and material to be suspended for the purpose of applying a load to the hoist assembly. Necessary safety equipment, including barriers, shall be provided by the ETL. The personnel performing the test shall consist of a qualified mechanical engineer from Characterization Engineering, with the support of ETL personnel familiar with the operating procedures of test equipment in the ETL.

\subsection{TEST DOCUMENTATION}

A simple table will be prepared for recording the data that is collected during the test, an example of the table is included in Appendix B. The data table will contain, as a minimum, the intended load, the actual suspended weight, a checklist for pass/fail of "bird nesting" criteria and the "section" of cable being tested. Because the entire length of cable cannot be tested without repositioning the load, the test will be performed over 
sections of cable. The "sections" of cable will be described by their starting and ending distance from the eye-end of the cable. The original data table, or a copy of it, will be released as an appendix to the test report.

\subsection{TEST}

The engineer performing this test may interrupt the testing at any time if it is determined that design rework is necessary. If design rework is necessary the test will be reaccomplished in its entirety. If a minor adjustment is necessary during the test, the discretion of the engineer, with concurrence from the design authority or cognizant engineer, will be employed to determine whether the test can continue from the stoppage point, or whether further re-accomplishment of test sections is necessary.

\subsection{PRE-TEST SETUP}

4.1.1 The test apparatus, described in Section 3.4, shall be securely mounted in a location with a minimum distance below the hoist of $3.66 \mathrm{~m}(12 \mathrm{ft})$.

4.1.2 Prior to loading, the cable shall be hand-wound onto the drum, spooled out, and rewound with the motor, ensuring that no "bird nesting" conditions exist prior to actual performance of tests under the defined conditions found in Table 3.2.1.

4.1.3 The area below the hoist will be appropriately marked and barricaded to prevent unauthorized entry of personnel.

4.1.4 The specimens that provide the load are to be weighed and marked to streamline the actual testing.

4.1.5 The entire $22 \mathrm{~m}$ ( $72 \mathrm{ft}$.) length of cable cannot be tested without re-positioning the suspension tool, and therefore the load. The length of cable will be "sectioned" into lengths that are testable. The sections of cable shall be chosen to ensure that the transition from layer to layer of cable on the drum occur while testing a particular section (ie. the transition from layer to layer on the drum shall not occur at an extreme of a particular cable section). The section lengths will be determined prior to starting the tests and are dependent on the distance from the bottom of the hoist to the floor.

\subsection{TEST PROCEDURE}

The following procedure is to be performed over the full, testable length of the cable and at each of the intended loads described in Table 1. The length of the sections will be recorded on the test data form. The order in which the sections are tested is irrelevant. Furthermore, it is irrelevant whether the test is performed for a given load over all of the cable sections or whether each cable section is tested over all of the loads. In other words, all sections of the cable shall be tested with all of the loading conditions defined in Table 1, test order is not important.

\subsubsection{For each defined section and loading condition:}


4.2.1.1 Spool cable out from the drum so that the end of a cable test section is at the correct height to attach the load. At this section boundary, attach the suspension tool.

4.2.1.2 Secure the appropriate load to the suspension tool.

4.2.1.3 Operate the Grapple Hoist to wind the cable onto the drum. While the cable is being wound, the cable and the level wind assembly shall be monitored for bird nesting or failure/deformation of the level wind components. Stop the hoist when the suspended load is one foot below the bottom of the hoist assembly.

4.2.1.4 Lower the load back to the starting position.

4.2.1.5 Repeat steps 4.2.1.2 and 4.2.1.3 for a total of 25 trials per section/load combination OR until bird nesting or failure/malfunction of the level wind components occurs. If bird nesting or malfunction occur, correct the situation and continue with the test. Each trial shall be logged on the test data table.

4.2.2 Repeat 4.2.1.1 through 4.2.1.5 for each loading condition/cable test section combination.

4.2.3 For the Cable Alone loading condition, the suspension tool is not necessary, but the test will still need to be performed in sections-a loop of cable will be secured and repositioned, as necessary, to ensure that the entire weight of the cable is suspended under the hoist. Substitute 4.2.1.1 and 4.2.1.2, respectively, with:

- Spool $22 \mathrm{~m}(72 \mathrm{ft}$.) of cable off of the drum.

- Roll the cable and secure to the section boundary closest to the hoist.

The test steps that follow shall be performed after completion of steps 4.2 .1 through 4.2.3

4.2.4 Apply a liberal coat of Quick-N-Brite ${ }^{\circledR}$, a product used as a fixative and decontamination agent, with a spray bottle to the "in-box" components. It is not necessary to coat the entire cable length, a nine meter $(29.5 \mathrm{ft}$.) section is adequate. Allow to dry a minimum of eight hours. Attach a $445 \mathrm{~N}$ (100 lbf) weight to the cable. Raise and lower the weight approximately nine meters a total of ten times. Note on data sheet whether there are any problems or abnormal behavior during this test.

4.2.5 Attach a sampler piston (old style) to the floor, or other stationary object. Connect a cross-drilled pintle rod to the sampler piston with $150 \mathrm{lbf}$ shear wire. Attach the Grapple Hoist cable to the grapple, after routing the cable through a vertical section of drill string or pipe approximately three meters $(10 \mathrm{ft}$.) tall, and attach the grapple to the pintle rod (see Sketch A). Record the load cell reading on the data sheet with a slack cable. Raise the hoist until shear of the wire occurs. Record the peak load as well as any effects of the "shock load" on the system on the data sheet. Repeat five times for each layer of cable that is capable of being tested; anticipated testable layers are one, two and a portion of three. 
HNF-4740, Rev.1

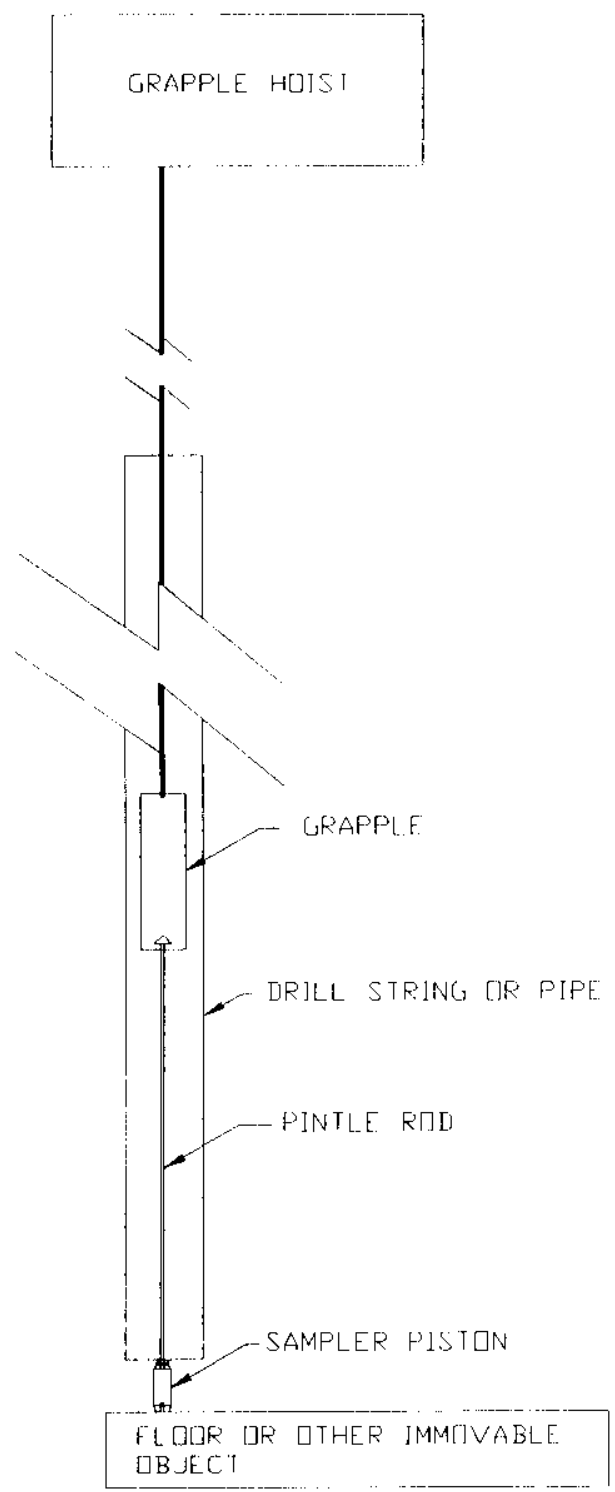

SKETCH A 
HNF-4740, Rev.1

\subsection{REFERENCES}

Drawing, Hanford Document Control, H-2-690057 Sheet 1-7, Grapple Hoist Assembly, RMCST, Hanford Site; Richland, WA

Drawing, Hanford Document Control (unreleased, Development Control), H-2-690057 Sheet 1-6 and 8, Grapple Hoist Assembly, RMCST, Hanford Site; Richland, WA (Included in the Appendix)

Drawing, Hanford Document Control, H-2-690055 Sheet 1-5, Grapple Hoist Installation, $R M C S T$, Hanford Site; Richland, WA

Drawing, Hanford Document Control, H-2-690071 Sheet 1-17, Electrical Connection Diagrams, RMCST, Hanford Site; Richland, WA

LMHC 1998, HNF-SD-WM-SEL-044, Rev. 2, A Safety Equipment List for Rotary Mode Core Sampling Systems Operation in Single Shell Flammable Gas Tanks, COGEMA Engineering Corporation; Richland, WA

LMHC 1999a, HNF-IP-0842, Vol. IV, TWRS Engineering, Sec. 4.26, Rev. 0, Supporting Document Requirements, Lockheed Martin Hanford Corporation; Richland, WA

LMHC 1999b, HNF-IP-0842, Vol. IV, TWRS Engineering, Sec. 4.28, Rev. 0, Testing Practices Requirements, Lockheed Martin Hanford Corporation; Richland, WA 
HNF-4740, Rev.1

APPENDIX A

TEST APPARATUS AND

LEVEL WIND ASSEMBLY 


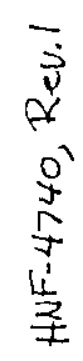
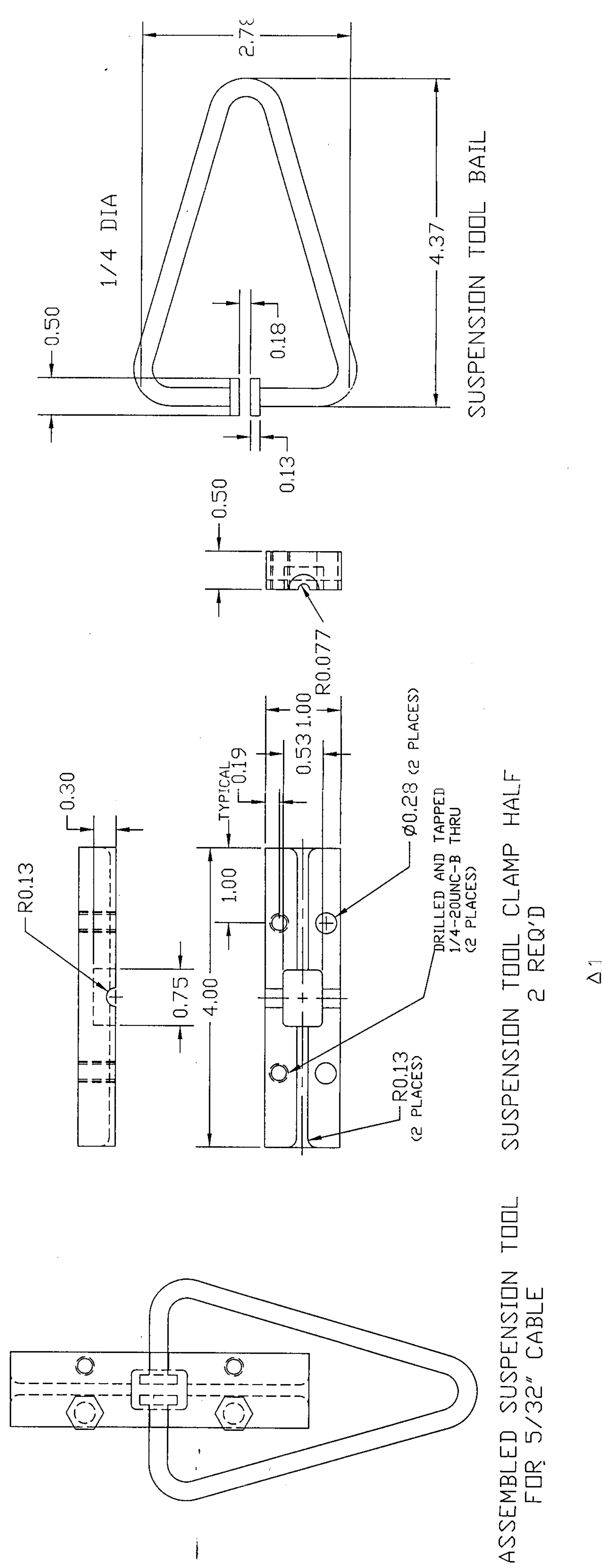


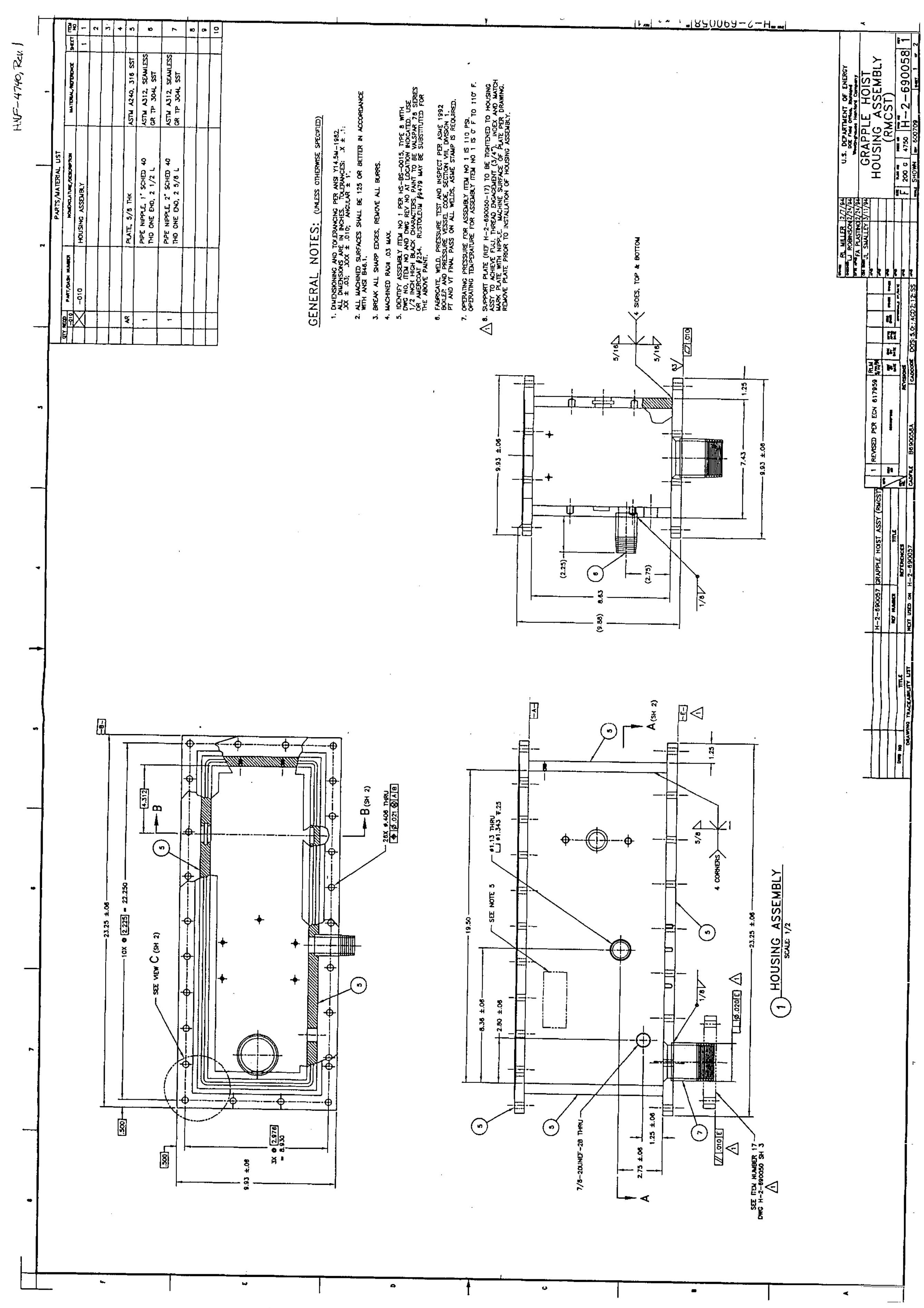




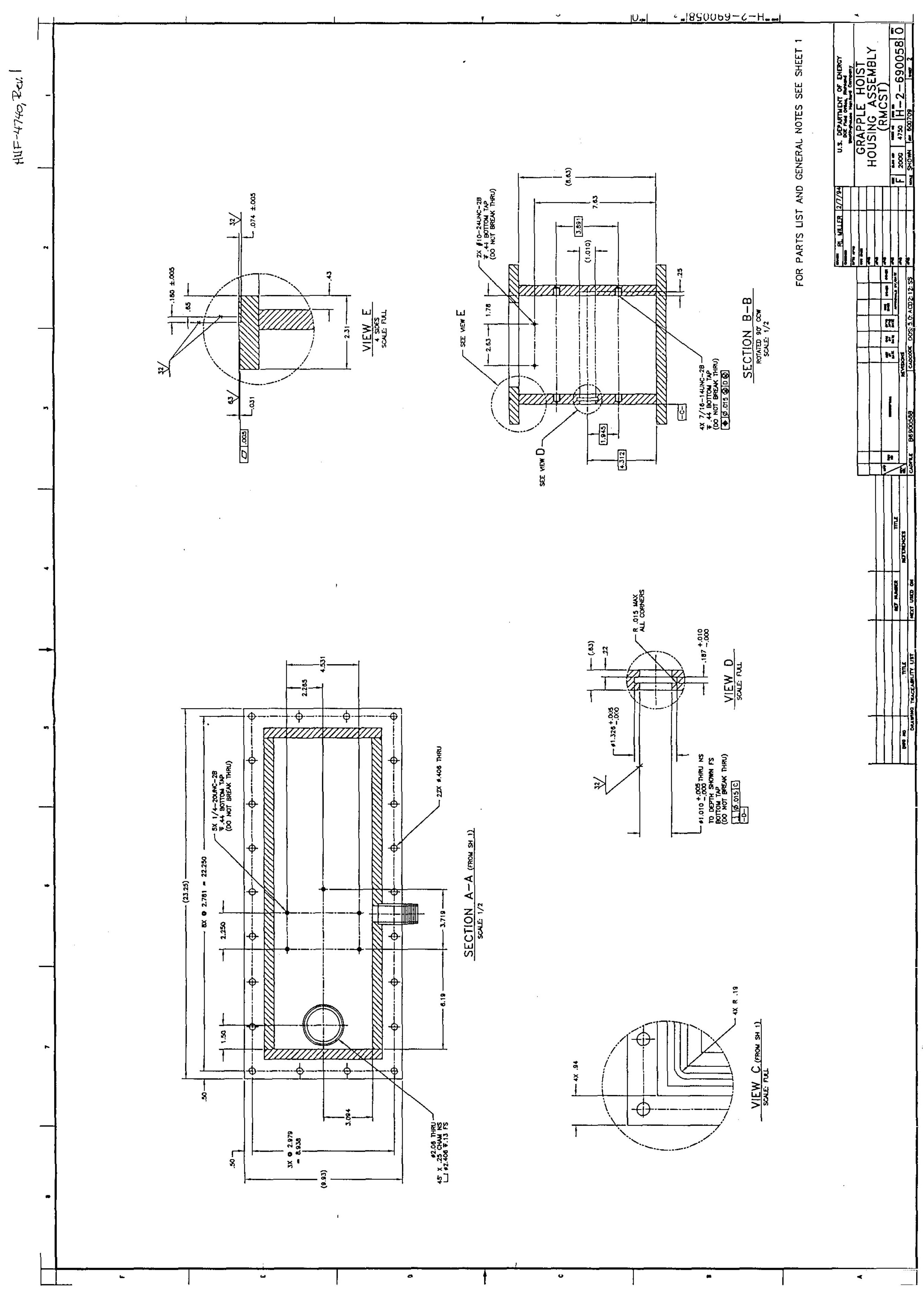




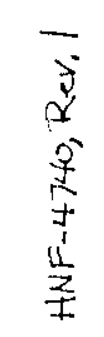
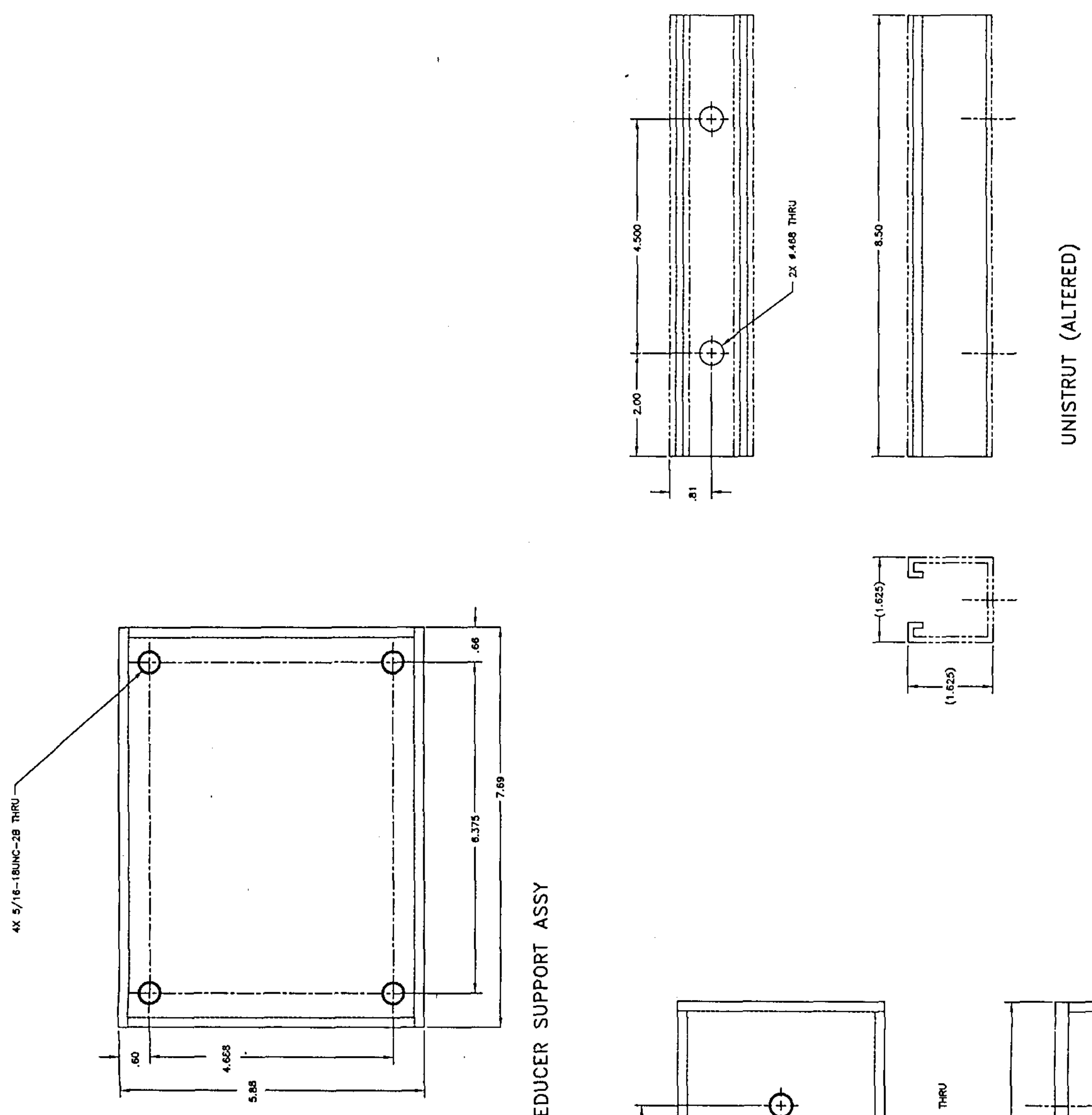

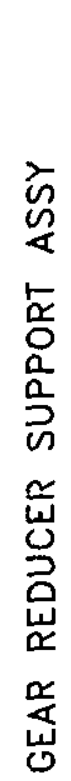
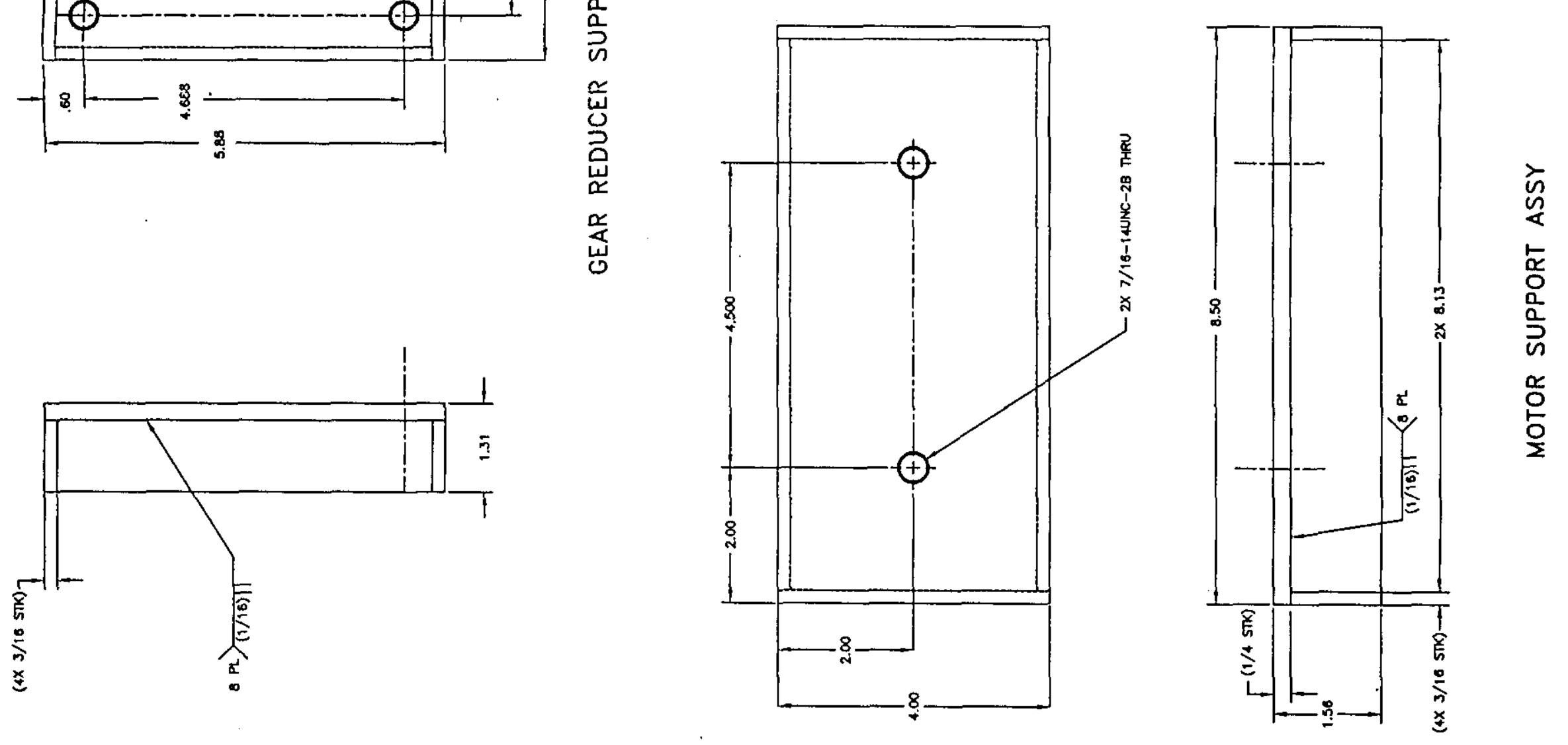


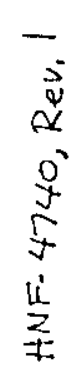

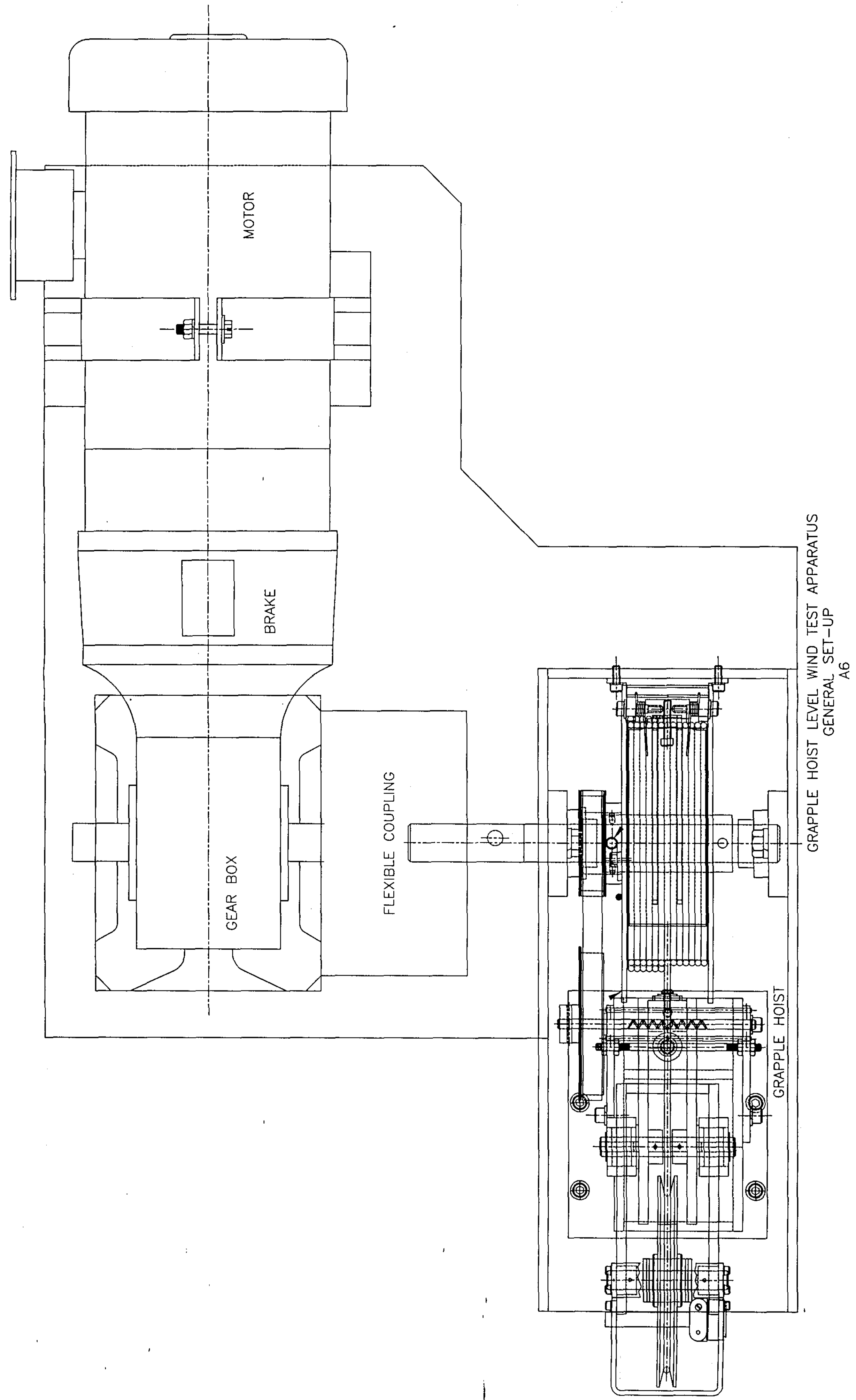


(1)

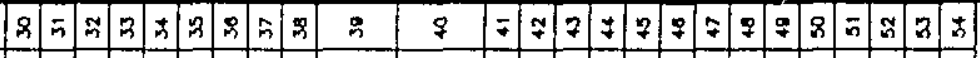

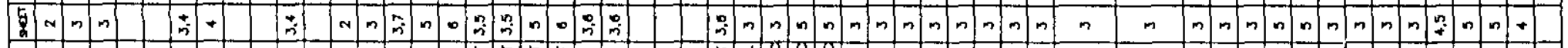

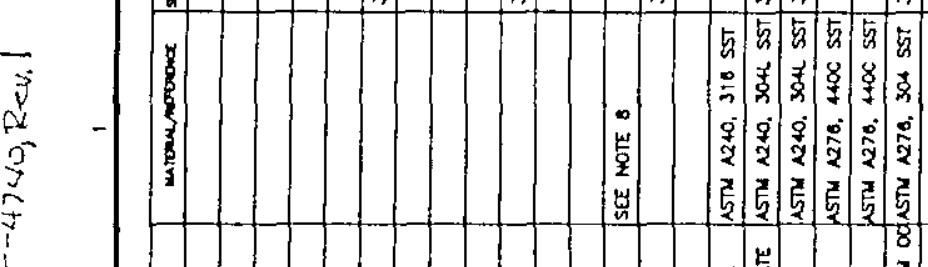

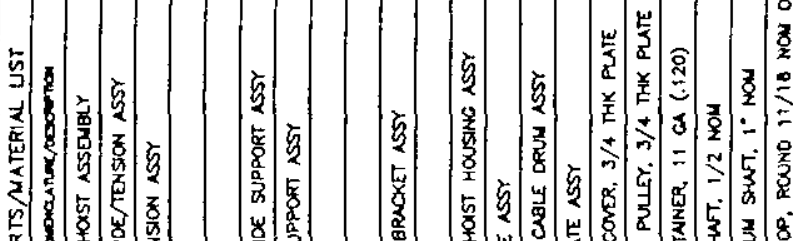

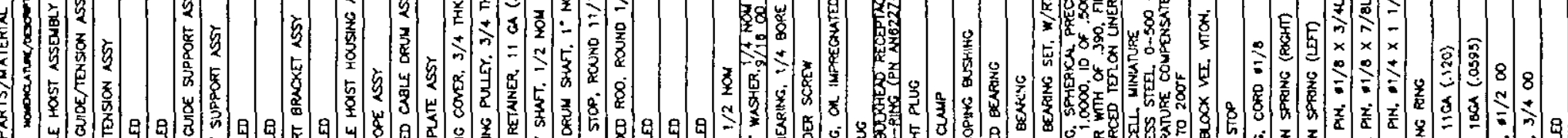

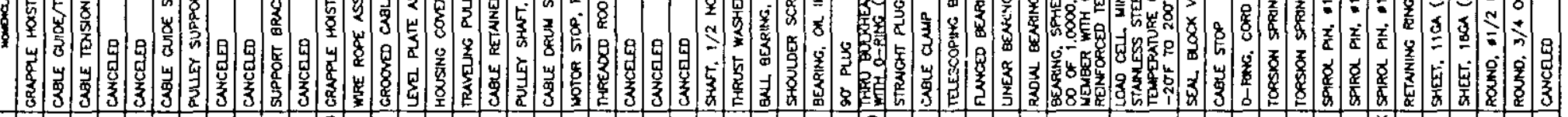

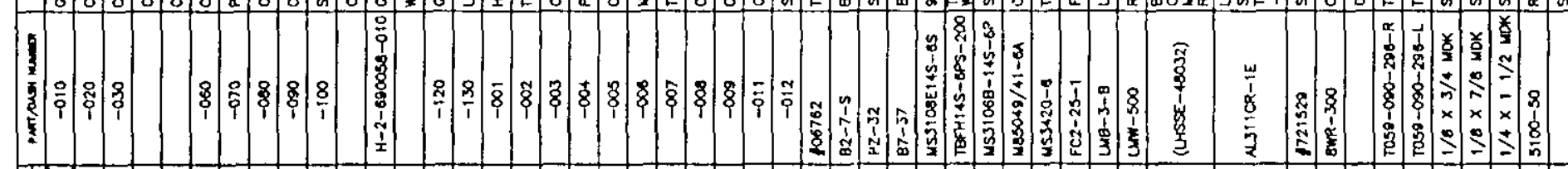
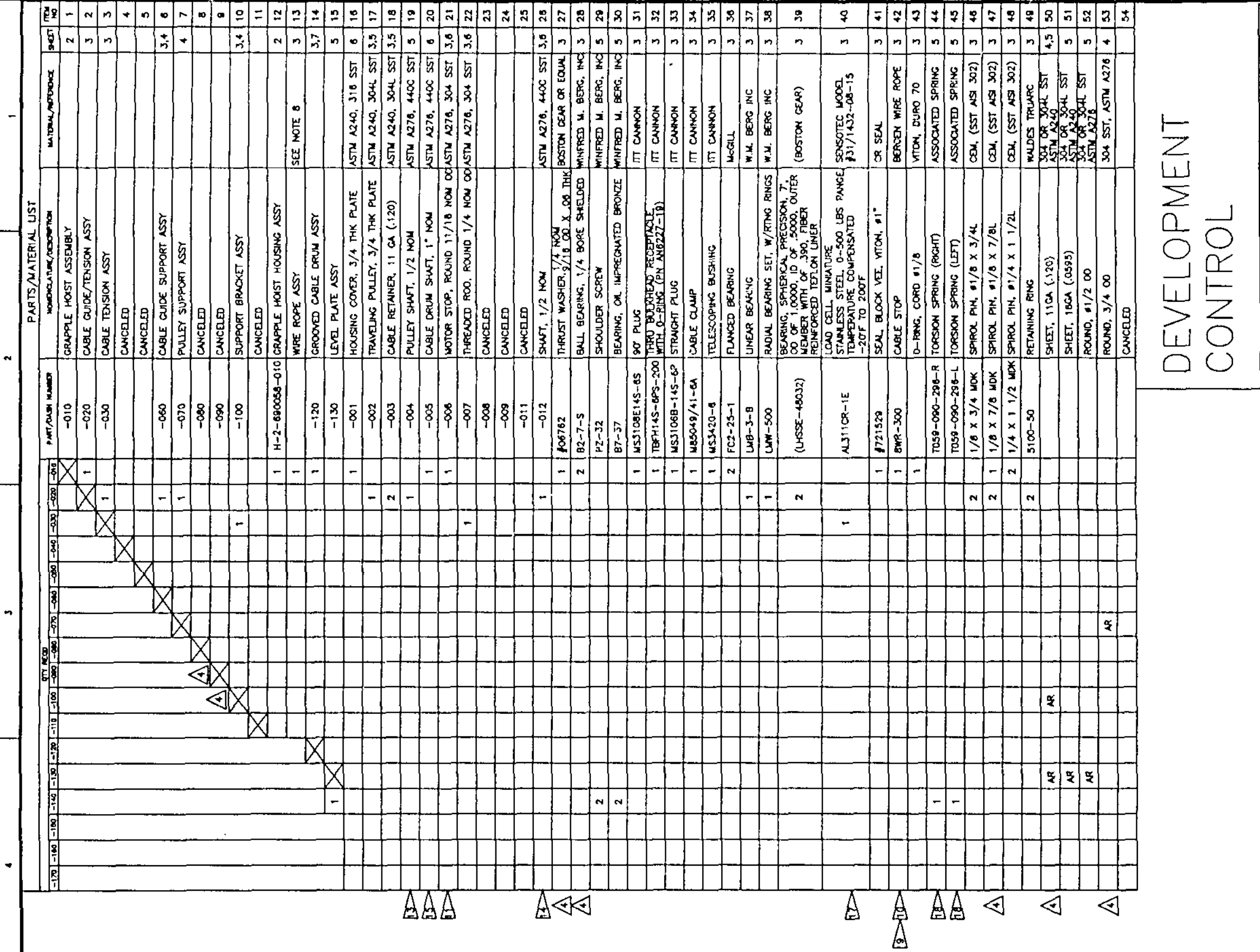

$\rightarrow$

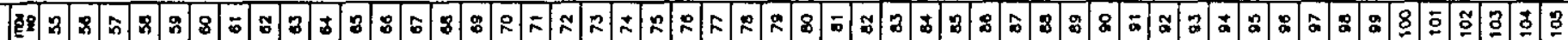
(1)

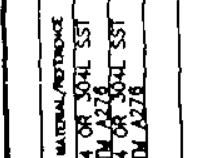

等

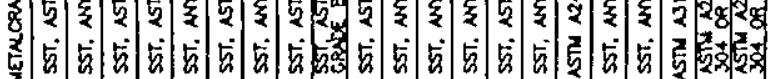

5 (

\%

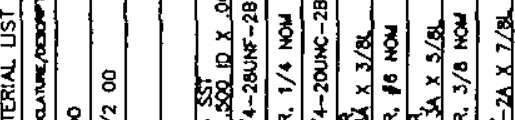

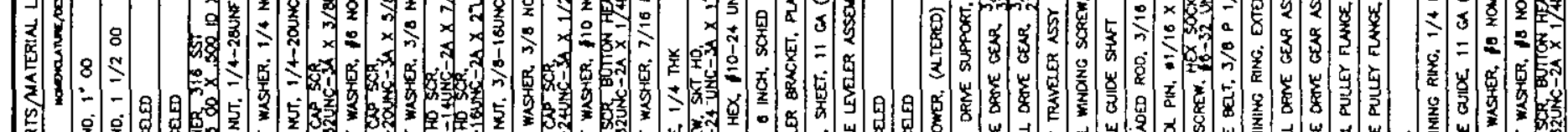

等

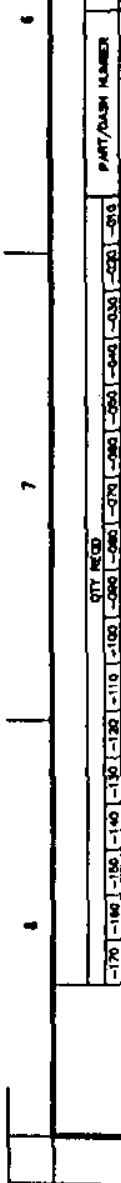

影

(1)

.

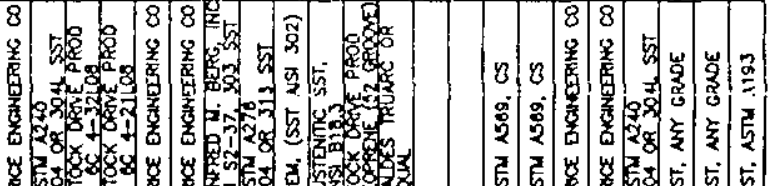

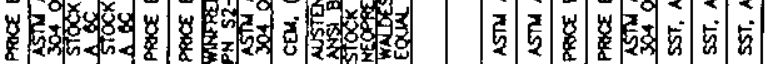

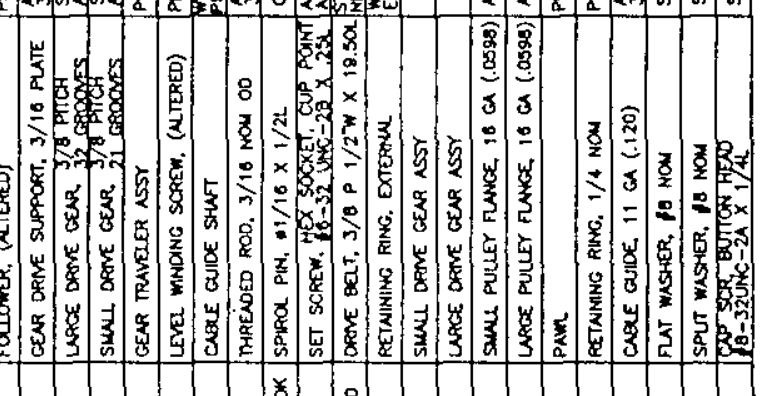

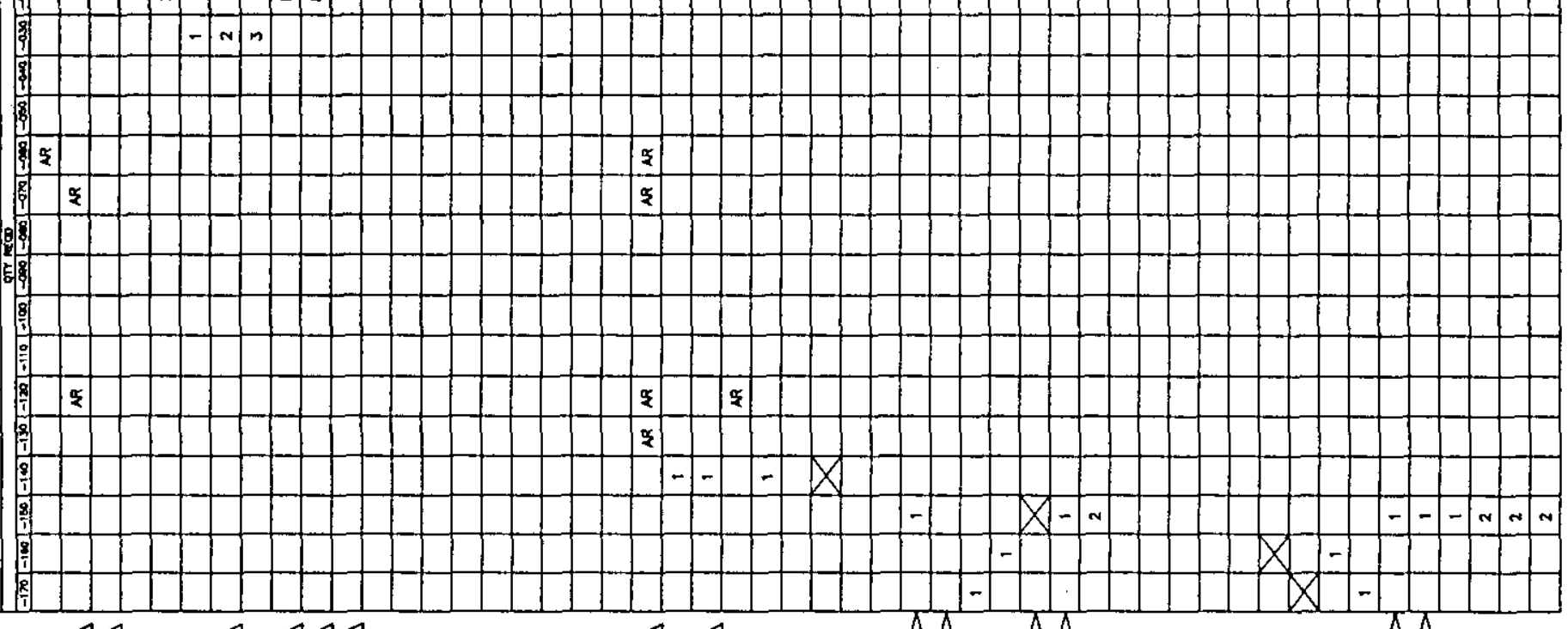

水 帎丹

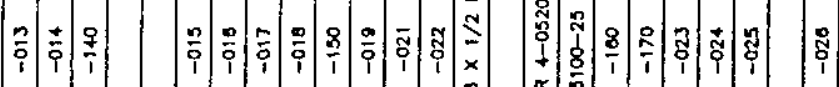
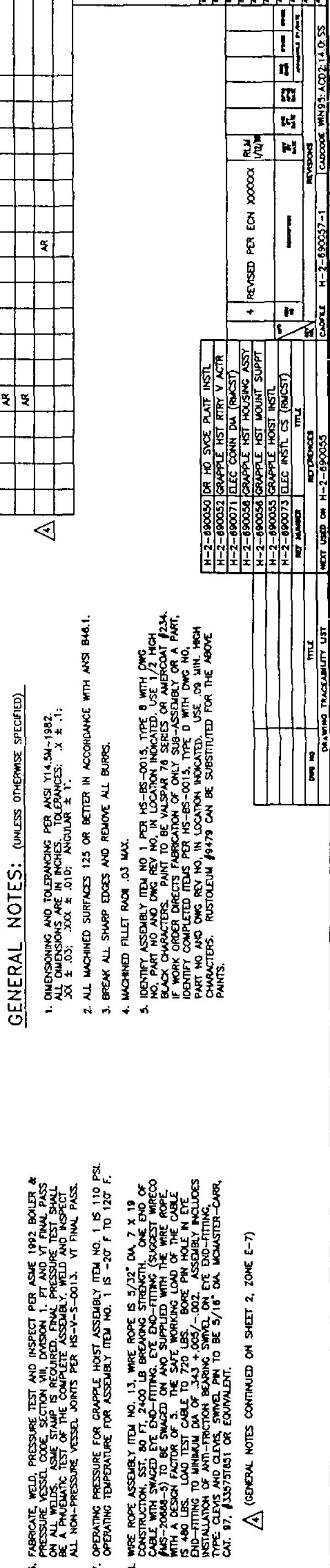


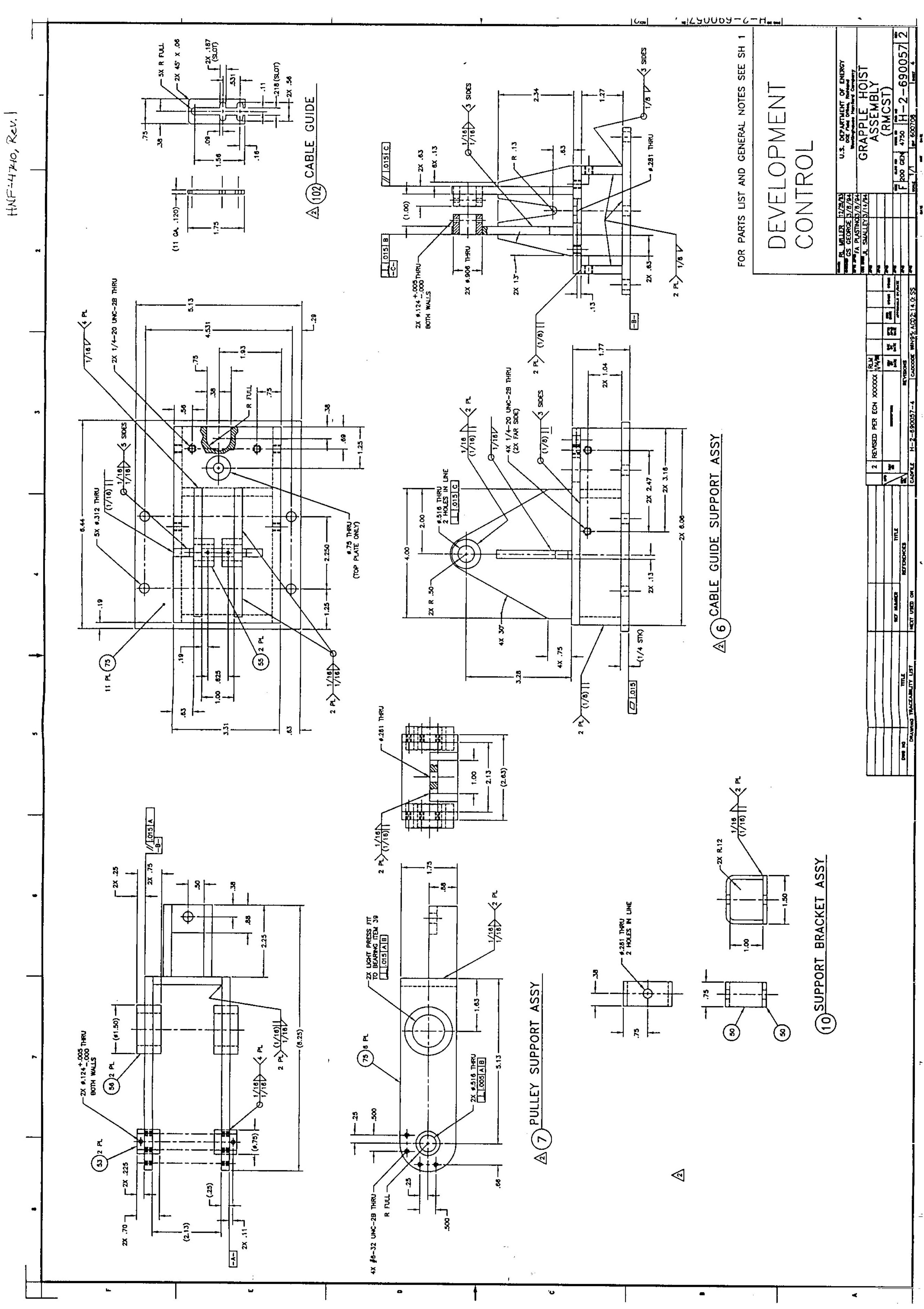




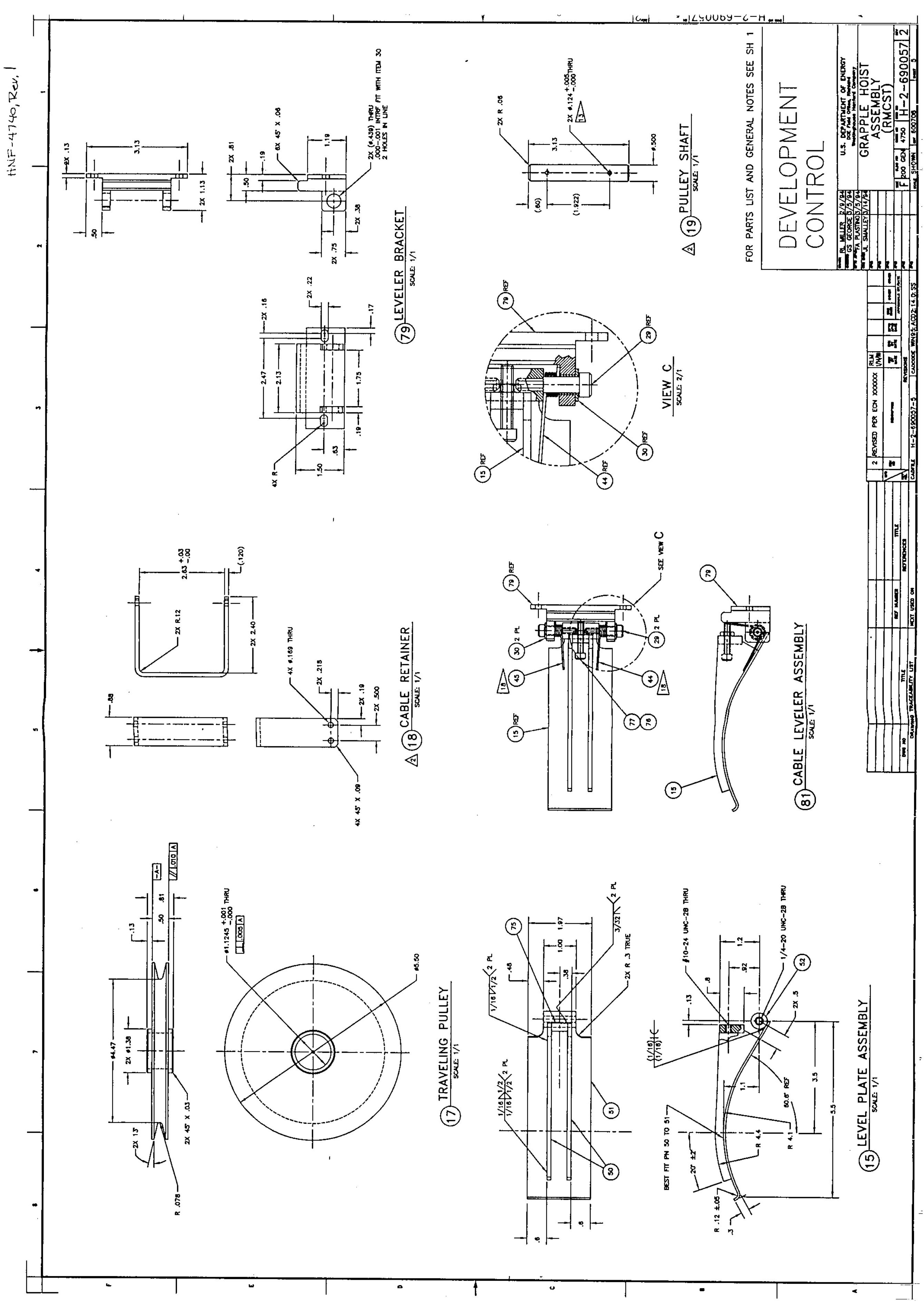




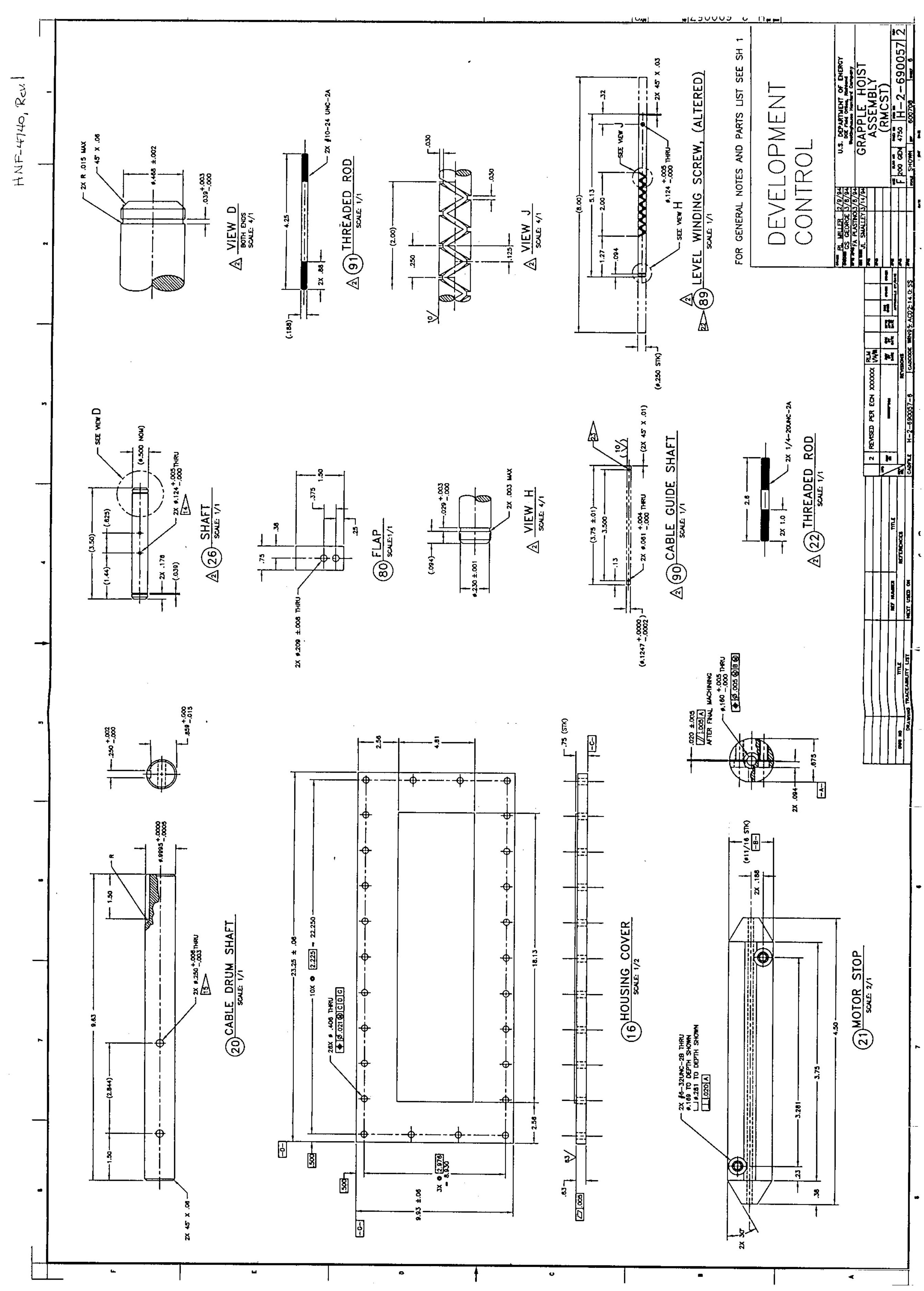




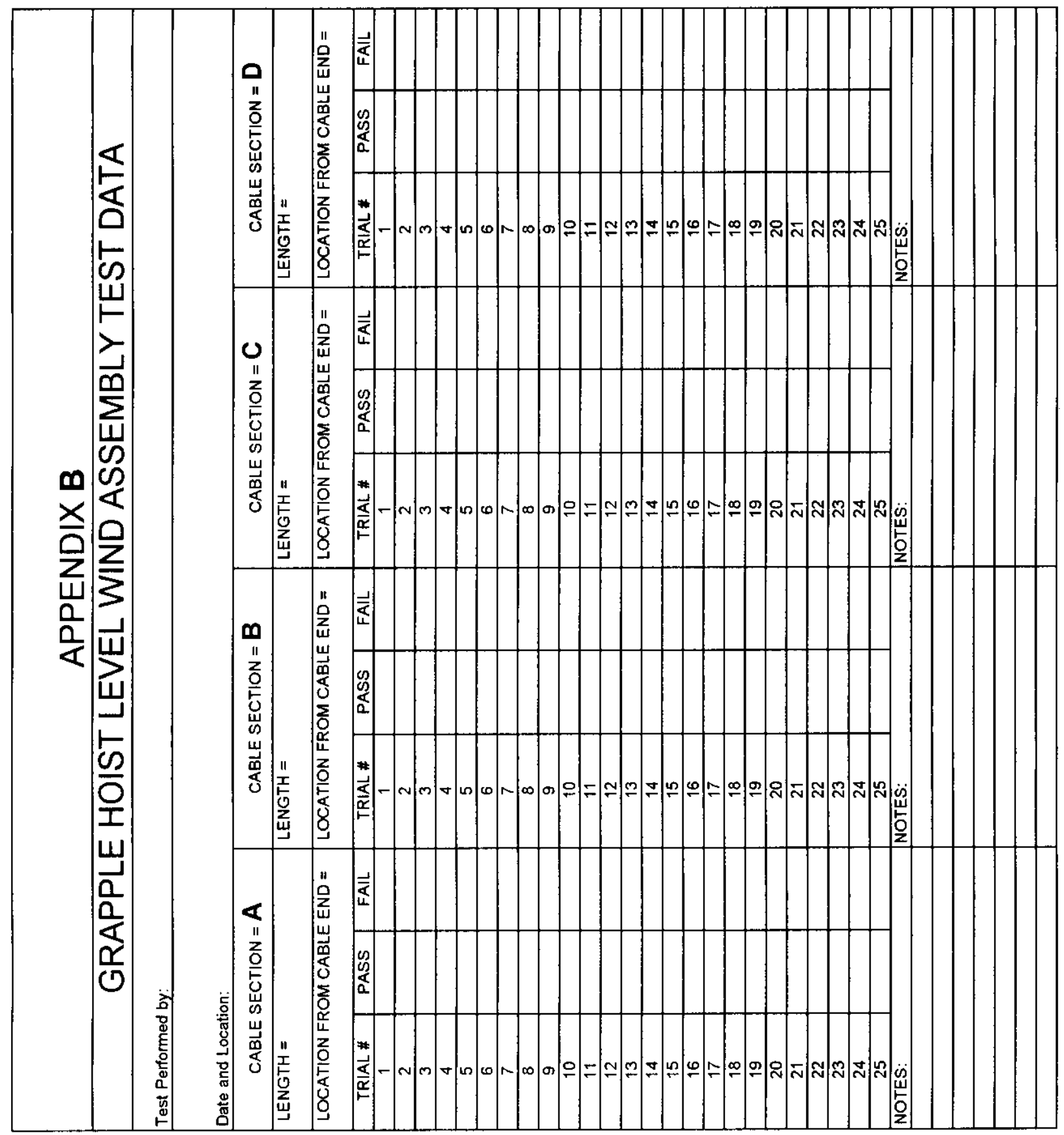

